\title{
EL «INTERLOCUTOR» NARRATIVO DE CARMEN MARTÍN GAITE DESDE UNA PERSPECTIVA BARROCA Y CERVANTINA
}

\author{
ANTONIO REY HAZAS \\ Universidad Autónoma de Madrid
}

Introducirse en la interesante obra novelesca de Carmen Martín Gaite es verse inmerso en una creación literaria de profunda coherencia artística, y ello porque no se limita a «decir» con calidad estética, ni siquiera a «hacer», sino que «hace lo que dice», por expresarlo con palabras de Pedro Salinas. La indagación realizada al respecto, desde la óptica, central para esta autora, del interlocutor, ha encaminado mis pasos, curiosamente, hacia el Barroco novelesco español y, en concreto, hacia Cervantes.

TEORÍA LITERARIA

El ideario novelesco de nuestra escritora, acerca del lugar medular que ocupa el interlocutor en su quehacer narrativo es bien conocido, y se encuentra desperdigado por varios escritos suyos de diferente índole, aunque ello no obsta para que sea de una gran consistencia teórica. Resumiéndolo mucho, podría esquematizarse más o menos así: 
a) Necesidad universal, general y psicológica del interlocutor como motor postrero de la conducta humana: La autora dice haber «comprobado» que hay un «asunto» al que «más tarde o más temprano, acaba remitiendo cualquier posible reflexión sobre los conflictos humanos: el de la necesidad de espejo y de interlocución, se sepan o no buscar. Necesidad enmascarada por un cúmulo de circunstancias adversas y de interpretaciones falaces, pocas veces confesada y menos satisfecha, pero que nunca, aun cuando se reniegue agresivamente de ella, deja de condicionar, como ultimo móvil, nuestros actos y nuestras omisiones» 1 .

b) Necesidad particular, concreta y nacional, dado que la interlocución es una de las más destacadas carencias o lacras españolas: «Es, en verdad, una situación a la que paulatinamente los españoles se han tenido que acabar resignando - dice la narradora-, ésta de que nadie les escuche. En pocos países como en el nuestro gustará tanto hablar y tan poco escuchar (...) Todos los españoles, más que ser oídos, quieren hablar sin que les interrumpan; el papel de oír, a nadie le gusta un pelo y muy pocos lo representan, y es precisamente ese reparto tan descompensado lo que les hace tan poco dotados para la comunicación»².

c) Necesidad individual, personal y autobiográfica, en tercer lugar, del espejo puro, del interlocutor virgen, que no someta a deformaciones falaces la realidad, ni la propia vida. Y ello porque aunque «a lo que más apego se tiene es a uno mismo», eso no basta, y «el propio yo viene a verse con una especie de telón despintado y engañoso que solamente una mirada ajena podría hacer creíble y reivindicar - al decir de la autora $\rightarrow 3^{3}$. La propia biografía agobia en ocasiones, la autocontemplación conduce a la infelicidad al menos desde Narciso; por eso se impone «esa sed de que alguien se haga cargo de la propia imagen -dice- y la acoja sin someterla a interpretaciones, un terreno virgen para dejar caer muerta la propia imagen, y que reviva en él» ${ }^{4}$.

1 Carmen MARTín Garte, «Prólogo a la primera edición» de La búsqueda del interlocutor y otras búsquedas, 1972, cito por la ed. de Barcelona, Destino, 1982, p. 7.

2 Carmen MARTiN GaITE, «Tres siglos de quejas de los españoles sobre los españoles», en La buisqueda del interlocutor y otras búsquedas, Barcelona, Destino, 1982, p. 77.

3 Carmen MARTin GarTe, «Los malos espejos» (1972), en La búsqueda del interlocutor y otras búsquedas, p. 18.

4 lbid., p. 17. 
d) Necesidad literaria, o mejor novelesca, tanto oral como escrita, del interlocutor, desde el punto de vista del narrador: La obligatoriedad del receptor en el relato hablado es obvia, y la escritora así lo constata: «si el interlocutor adecuado no aparece en el momento adecuado, la narración hablada no se da»5 . Pero no es el cuento oral lo que nos interesa en este momento, sino el escrito, aunque tenga forma de relato hablado; $y$ en este sentido las palabras expresas dentro de Retahilas son harto significativas: «... ni por las mientes se me estarían pasando semejantes retahílas con el orden que llevan si no estuvieras tú que me las vas guiando, y ese orden es su vida, su razón de existir; nunca lo había pensado, pero ahora lo veo clarísimo: las historias son su sucesión misma, su encenderse y surgir por un orden irrepetible, el que les va marcando el interlocutor, aunque no interrumpa, es según te mira, ahora las desvía por aqui, ahora por alla, a base de mirada, y nunca dan igual unos ojos que otros; el que oye, sí, ése es quien cataliza las historias, basta con que sepa escuchar bien» 6 .

La novela, la narración literaria,obvio es decirlo, se diferencia bastante, sobre todo porque da mayor libertad, toda la libertad, al narrador, que no tiene que someterse a las limitaciones de la realidad circundante: «el narrador literario las puede quebrar - dice la novelista-, saltárselas; puede inventar ese interlocutor que no ha aparecido, y, de hecho, es el prodigio más serio que lleva a cabo cuando se pone a escribir: inventar con las palabras que dice, y el mismo golpe, los oídos que tendrían que oírlas»?

e) Necesidad del interlocutor-espejo en la armonización indisoluble de vida y literatura: Carmen Martín Gaite une sin fisuras, funde con perfecta consonancia vida y literatura, por lo que el interlocutor, fundamental para ambas por separado, es indispensable también en la fusión; y ello porque nos encontramos ante una literatura básicamente biográfica y ante una vida que se rehace y se revive constantemente en moldes literarios. A esta concepción de la vida como relato se debe que la escritora prefiera el término narrativo *contar» a las palabras biográficas «recordar» o krevivir», porque en toda evocación «existe un primer esbozo narrativo donde se contiene ya el germen esencial y común a toda invención literaria: la facultad de escoger. No es recordar, sino seleccionar los recuerdos de una determinada manera, lo que convierte al protagonista de cualquier situación, cuya mera repetición fotográfica no le puede

5 «La búsqueda del interlocutor» (1966), 0p. cit., p. 25.

6 Carmen Martin Garte, Retahilas (1970), cito por la segunda ed., Barcelona, Destino, 1981. p. 100.

7 lbid., p. 26. 
contentar, en narrador (o sea sujeto y artífice) de ella» ${ }^{8}$. Resulta obvio, por otra parte, y dicho sea de paso, que se trata de una estética novelesca nada realista, dado que no le interesa la «repetición fotográfica».

\section{Algunas Claves Teóricas de la Novelística Autobiográfica de CARMEN MARTIN GAITE}

f) La diferencia entre experiencia personal de vida y narración biográfica se centra en que la novela modifica siempre lo vivido y nunca realiza una transcripción fiel de la realidad tal y como fue: «Cuando vivimos, las cosas nos pasan; pero cuando contamos, las hacemos pasar - asegura, sutilmente, la escritora-; y es precisamente en ese llevar las riendas el propio sujeto donde radica la esencia de toda narración (...) No se trata, pues, solamente del deseo de prolongar por algún tiempo más las vivencias demasiado efímeras, trascendiendo su mero producirse, sino de hacerlas durar en otro terreno y de otra manera: se trata, en suma, de transformarlas»?.

g) El relato autobiográfico, por otro lado, no se limita a modificar la experiencia, mediante la transformación que escoge, selecciona y ordena sus frutos, sino que va más allá, y utiliza materiales ajenos a la realidad personalmente vivida; y ello, en dos sentidos: 1) ya incluyendo lo que pudo ser y no fue (:«junto a lo ocurrido, raras veces se dejará de tener presente lo que estuvo a punto de ocurrir o lo que se habría deseado que ocurriera» ${ }^{10}$ ); ya insertando dentro de lo biográfico el ámbito de la ficción inventada, el mundo de la experiencia leída y el entorno del sueno: el narrador autobiográfico «no se limita casi nunca -en palabras de la novelista- a elegir una ordenación particular, a preferir unos detalles y dejar otros en la sombra, sino que recoge también de otros terrenos que no son el de la realidad - lecturas, sueños, invencionesnuevo material con que moldear y enriquecer su historia»"

8 «La búsqueda del interlocutor», op. cit., p. 21.

9 Ibid., p. 22.

10 Ibid., p. 23

11 lbid., p. 23. 
h) La vida narrada se aproxima a la concepción de la literatura como juego y pasa a formar parte de la literatura fantástica y de misterio: en coherencia con lo que acabamos de exponer, la novelista se muestra claramente partidaria de incluir la creación literaria "entre las empresas lúdicas» ${ }^{2}$; y de insertarla dentro de la vena ficticia y fantástica, tras los pasos de Todorov. En su novela clave El cuarto de atrás, en cuyo análisis centraremos buena parte de este trabajo, dice: "Ahí está el libro que me hizo perder pie: Introducción a la literatura fantástica de Todorov (...), hablaba de los desdoblamientos de personalidad, de la ruptura de límites entre tiempo y espacio, de la ambigüedad y de la incertidumbre...»13.

i) La época clave para el recuerdo y el relato biográfico es la pubertad, en opinión de la narradora: «la adolescencia, que es cuando más nos deslumbra todo lo que nos pasa y cuando más tendencia tenemos a magnificarlo, puede explicar el fenómeno de que algunos recuerdos de infancia y juventud surjan de pronto, cuando menos lo esperábamos, perfectamente elaborados» ${ }^{14}$.

\section{La Práctica Novelesca: «El Cuarto de ATRÁS»}

Aunque sería muy interesante rastrear la aparición del interlocutor en toda la obra novelesca de Carmen Martín Gaite, he optado por analizar El cuarto de atrás, y ello por dos razones, además de por su reconocida calidad estética (obtuvo el Premio Nacional de Literatura en el año 1978); a saber: 1) porque es el mejor ejemplo de la coherencia plena que hay entre la creación narrativa y la teoría literaria de esta autora; y 2) porque, simultáneamente, se presta mejor que ninguna otra novela a la comparación de su técnica con el uso barroco y cervantino del interlocutor narrativo, que es el propósito principal de este artículo.

El cuarto de atrás, como ya hemos anticipado, se sitúa voluntariamente a la zaga de Todorov, por lo que se autodefine, al menos en parte, como no-

12 lbid., p. 29.

13 Carmen Martí GaITE, El cuarto de atrás (1978), cito por la cuarta ed., Barcelona, Destino, 1988, p. 19.

14 «La búsqueda del interlocutor», 23. 
vela fantástica, y no sólo a causa de la cita transcrita más arriba, sino también porque la narradora dice de inmediato: «Palabra que voy a escribir una novela fantástica». Al mismo tiempo, la novela se configura como relato autobiográfico, ya desde su mismo título, que evoca el viejo «cuarto de jugar y de dar clase» que presidió la infancia y adolescencia de la escritora en su casa salmantina; época clave, como sabemos, según la concepción narrativa de Carmen Martín Gaite. La novela de hecho se inicia mediante la evocación de esa habitación trasera, con cama turca y teléfono negro en el pasillo, ubicada en un piso primero abalconado sobre una pequeña plaza de una ciudad provinciana, realizada desde el cuarto actual de la narradora, con cama grande, teléfono blanco al alcance de la mano, y situado en el piso último de un rascacielos madrileño. Un cuarto evoca a otro, en marcado contraste. El pasado revivido se resucita desde un presente misterioso. Ambas cosas, pues, lo fantástico-ficticio y lo autobiográfico-real van unidas desde el primer momento.

Y es que todo lo actual se tiñe de una nebulosa ficticia a la búsqueda del interlocutor imprescindible en el momento de contar-recordar: son las diez de la noche; la narradora lee una carta inmensa, que ocupa todo el pasillo, dirigida a ella por un desconocido desde un playa ignota. ¿Es real? ¿Es apócrifa? No queda claro (la incertidumbre, no se olvide, es uno de los rasgos de la literatura fantástica que citaba), aunque parece ficticia, porque la autora dice que le gustaba escribirse cartas a sí misma. En todo caso, Carmen piensa que podría encontrarse con ese hombre desconocido en la misma playa donde ella veraneaba en su adolescencia y hablar con él (el tiempo y el espacio se anulan, como pedía Todorov y aceptaba la novelista); y, lo que es más importante, se ha encontrado («inventado») ya un interlocutor: el autor de la epístola. A él se refiere la narradora: «Y al contarlas en voz alta, salvaría del olvido todas las cosas que he estado recordando y sabe Dios cuántas más; es incalculable lo que puede ramificarse un relato cuando se descubre una luz de atención en otros ojos» ${ }^{15}$. El desdoblamiento que solicitaba Todorov, por otra parte, ya se ha dado entre la Carmen actual en su cuarto madrileño y la niña (ella) que leía una revista bajo la luz amarilla en el viejo «cuarto de atrás».

Sin embargo, la novela no ha hecho más que iniciarse, e introducirnos en un mundo mágico y real a un tiempo. El receptor de la carta (auténtica o irreal) desaparece pronto y cede su lugar al interlocutor fundamental: «un hombre vestido de negro con sombrero negro de alas anchas», un ser extraño y misterioso, que aparenta ser un entrevistador a pesar de que Carmen asegura no sa-

15 El cuarto de atrós (1978), Barcelona, Destino, cuarta, 1988, p.22. 
ber «de qué entrevista se trata»; un individuo que lleva un «mechero antiguo de mecha amarilla» y huele a «loción de brea». Son las doce y media. Estamos en el capítulo segundo.

En este momento comienza a desarrollarse el meollo del relato, pues este interlocutor estará presente en él, de manera explícita o implícita, hasta el final del mismo, hasta el capítulo séptimo, en el que la hija de Carmen llega y la despierta, a las cinco de la mañana. La obra, pues, como tantas otras narraciones españolas contemporáneas, abarca un tiempo sumamente reducido, desde las diez de la noche hasta las cinco de la madrugada (aunque la rememoración incluya muchos años de la vida de Carmen Martín Gaite), y no sale del pequeño espacio del piso de la narradora, a pesar de que la retrospección del recuerdo lo amplíe muchísimo: a Salamanca, Galicia, Lisboa, Madrid, a otras casas y a otros ámbitos ${ }^{16}$. La incertidumbre y la ambigiedad presiden toda la novela, con el objeto de que nunca se sepa con certeza si estamos en el mundo de la ficción o en el de la realidad. No obstante, yo creo que hay una marca clave que abre y cierra el ámbito de la ficción y nos puede permitir establecer un cierto deslinde: se trata de las cucarachas. Cuando Carmen va a abrir la puerta al «entrevistador» de negro (cap. II) ve una enorme cucaracha «del tamaño de un ratón», fenómeno claramente fantástico. Pues bien, a partir de ese momento no vuelven a aparecer cucarachas hasta que, al final, llega su hija, quien antes de acostarse vuelve a ver una enorme cucaracha (cap. VII). Entre ambas menciones del insecto se mueven la fantasía y el sueño; antes y después la realidad. Este recurso me recuerda muchísimo al utilizado, allá en el siglo XIV, por Don Juan Manuel en el que constituye quizá el mejor de los cuentos de El Conde Lucanor, me refiero al de Don Illan de Toledo, cuento, por cierto, modernizado ( $\mathrm{y}$ no mejorado) nada menos que por Borges en su Brujo postergado. En él, un deán de Santiago llega a Toledo para que don Illán, el mago, le enseñe las artes de la nigromancia, y éste, antes de iniciar sus lecciones, le dice a su criada que cocine unas perdices. Empieza entonces una ficticia carrera de ascensos para el deán. que pasa a ser obispo, arzobispo, cardenal y llega incluso a lograr la tiara pontificia, mostrando siempre un desagradecimiento ostensible hacia su maestro, quien, finalmente, vuelve a llamar a su criada y le solicita las perdices que le había encargado al principio: en ese punto se acaba el sueño fantástico, y el mago despide al ambicioso e ingrato deán de Santiago. En El cuarto de atrás las cosas parecen similares, porque la hija encuentra a Carmen dormida en su cama, cuando

16 Véase el excelente análisis de este procedimiento realizado por Darío Villanueva, Estructura y tiempo reducido en la novela, Valencia, Bello, 1977. 
ella se había dormido en el sofá junto al hombre de negro al finalizar el cap. anterior, el VI. Todo parece indicar que ha sido un sueño. Sin embargo, no todo es así, porque también dice la hija que hay dos vasos en la bandeja. $i \mathrm{Ha}$ tenido una visita real? La ambiguiedad permanece, como en buena literatura fantástica, pero las incitaciones que sugiere la comparación pueden ser útiles para delimitar en buena medida lo real de lo soñado, aunque no completamente.

Asimismo, con la llegada del hombre de negro, la narración se une al proceso de la creación narrativa y la novela se configura, sin menoscabo para lo relatado, como metanovela. Nada más hacer su entrada en el piso, el entrevistador ficticio (tal es la libertad del escritor, recordémoslo: inventar su interlocutor) pone su sombrero sobre unos folios escritos a mano y a máquina: son quince, y el que está en la maquina de escribir se refiere expresamente al desconocido autor de la carta que había aparecido en el cap. I: «al hombre descalzo - dice- ya no se le ve». Estamos en el cap. II. Al comenzar el capítulo IV, los folios son ya setenta y nueve, y el que ocupa la máquina alude al conjuro cervantino de La Gitanilla, que había aparecido después de la aparición del «entrevistador». Finalmente, cuando llega su hija en el cap. VII hay ciento ochenta y dos folios numerados: El cuarto de atrás está acabado.

Es, pues, un texto autoreflexivo, que hace una novela y dice cómo se va haciendo dicha narración. Aunque lo interesante, a lo que creo, no es sólo que sea así, como tantos otros relatos de la novelística española actual, sino que lo sea gracias a la creación simultánea de un interlocutor, que es la verdadera clave del arco novelesco y metanovelesco.

Desde que el interlocutor de negro aparece, entran con él en escena el misterio, la fícción, los sueños y la fantasía, junto con la biografía real de Carmen Martín Gaite; porque este inventado entrevistador «lo sabe todo» ${ }^{17}$ acerca de su vida y de su obra, aunque la narradora no lo conoce en absoluto. ¿Se trata de un desdoblamiento de su conciencia? Probablemente. La ambigüedad queda en todo caso garantizada, como corresponde a la novela fantástica.

Al hilo de la mirada conductora del relato que el hombre de negro aporta a la novela, van aflorando los recuerdos biográficos de Carmen (Galicia, el viaje a Portugal con veinte años, sus relaciones amorosas con un portugués), al mismo tiempo que las rememoraciones de sus lecturas (La Gitanilla de Cervantes, la novela rosa: «cuanto me gustaba la novela rosa» ${ }^{18}$ ). De este modo, experiencias biograficas, lecturas y viajes se unen, tal y como propugnaba te6-

17 El cuarto de atrás, p. 58.

18 Ibid., p. 39. 
ricamente la autora, de manera desordenada, saltándose las fronteras del tiempo y del espacio (como también quería); aunque este desorden subjetivo se contrapese, de vez en cuando, mediante la tendencia opuesta a la objetividad ordenada, a las fechas precisas. Y es que otra de las claves de la novelística autobiográfica de Carmen se cifra en la tensión entre apego a la historia y gusto por la ficción; por eso, cuando dice vivir en la casa madrileña desde el año cincuenta y tres, reflexiona: «he vuelto a coger el hilo, como siempre que me acuerdo de una fechas ${ }^{19}$. No podía ser de otro modo, dada la dualidad de la escritora, escindida entre la pasión literaria y el afán por la investigación histórica (no sé si es necesario recordar sus ensayos sobre Macanaz, o sobre los usos amorosos en el XVIII y en la postguerra).

La autorreflexión, por otro lado, no se limita a esta novela, sino que abarca buena parte de su obra anterior, tanto narrativa como ensayística, aunque suele haber una considerable cohesión, conforme a la cual las reflexiones críticas sobre otros escritos sirven también para definir El cuarto de atrás. Así, por ejemplo, recuerda $E l$ Balneario, habla de su llegada biográfica al balneario de Cabreiroá, en Verín (Orense), de la extraña sensación de misterio que le causó, relata otras anécdotas de esta experiencia, y pasa a recordar su novela corta ya mencionada; en ese momento el interlocutor le dice: «Ese hombre que va con usted no se sabe si existe o no existe, si la conoce bien o no, eso es lo verdaderamente esencial, atreverse a desafiar la incertidumbre; y el lector siente que no puede creerse ni dejarse de creer lo que vaya a pasar en adelante, ésa es la base de la literatura de misterio». Esta autodefinición, obvio es decirlo, sirve perfectamente también para $E l$ cuarto de atrás.

El peculiar entrevistador soporta siempre buena parte de la carga teórica y crítico-literaria de la narración, aunque sus pensamientos al respecto recuerdan mucho a los que ya conocemos de Carmen Martín Gaite, lo que sugiere que se trata de un desdoblamiento ficticio de su propio "yo».

Este interlocutor-entrevistador, no obstante su carácter axial para la novela, cede momentáneamente su función a otros objetos y personajes. La narración se hace así autogeneradora de interlocutores, a partir del hombre de negro medular, mediante un procedimiento interesantísimo; veámoslo: En en cap. III Carmen va a la cocina para buscar el termo de té, deja al entrevistador en el salón, y se encuentra reflejada en el viejo espejo procedente de la casa de sus abuelos paternos; recuerda entonces sus viajes a esa casa de la calle Mayor de Madrid en Semana Santa o Navidad y, al hilo de ellos, ensarta las visitas a la modista que hacía su madre, y, a propósito, incluye un verda-

19 lbid., p. 47. 
dero ensayo acerca de modistas y costureras, y sobre cómo se vestían las mujeres de la postguerra española, etc. Pero no sólo el espejo se convierte en interlocutor mudo, sino que también le acompaña el aparador de castaño que decora su cocina, procedente del cuarto de atrás salmantino, herencia de su abuelo materno, el cual motiva la añoranza de su madre en Cáceres, donde también ella tenía su propio cuarto de atrás: «los recuerdos que pueden darnos alguna sorpresa - dice- viven agazapados en el cuarto de atrás, siempre salen de allí, y sólo cuando quieren, no sirve hostigarlos» ${ }^{20}$. Luego, rememora la educación nefasta, falsa y represiva de las mujeres durante la postguerra, lo que trae a colación su ensayo en ciernes sobre los usos amorosos de la postguerra... Sin embargo, a pesar de la sustitución pasajera, el interlocutor central sigue presente: «Querría hablarle al hombre de negro - dice Carmen- del vehículo narrativo que suponen los muebles, regalarle todas las imágenes que, en este rato, se me han aparecido entre el aparador y el espejom 21 .

El interlocutor básico reaparece en el cap. IV; este extraño entrevistador que «ni lleva programa, ni se esfuerza por agotar temas, todo queda insinuado, esbozado» ${ }^{22}$. No obstante, sí lleva raras píldoras de colores que avivan la memoria, "pero también la desordenan» ${ }^{23}$. Su función clave de catalizador de la narración no deja lugar a dudas. Animada por él, la narradora recuerda ahora un viaje a Burgos realizado en el año 1938 en compañía de su padre, su tío Vicente y su prima, para buscar el Pontiac negro que habían requisado a su progenitor por motivos militares, y estaba destrozado en un desguace. La memoria se incentiva a causa de la escapada que hicieron ella y su prima del hotel durante la noche, emocionante y novedosa. Enlaza después con otros recuerdos del franquismo, y explica las motivaciones que le llevaron a iniciar su ensayo sobre los Usos amorosos de la postguerra justo el día del entierro de Franco: ella había nacido el día de la muerte de Pablo Iglesias y de Antonio Maura, en diciembre de 1925, con lo que la defunción del Generalísimo en noviembre del 75 cerraba un círculo de cincuenta anos; un tramo de tiempo redondo, que se avivaba en su memoria merced al recuerdo de la hija de Franco, de Carmencita, coetánea de la autora, y de su mismo nombre, a quien ella había visto de niña... Todo ello justifica el comienzo del ensayo histórico y autobiográfico: «Se acab6, nunca más, el tiempo se desbloqueaba, había desa-

20 El cuarto de atrás, p. 91.

21 lbid., p. 97.

22 lbid., p. 106.

23 Ibid., p. 108. 
parecido el encargado de atarlo y presidirlo, Franco inaugurando fábricas y pantanos, dictando penas de muerte.... ${ }^{24}$.

$Y$ de nuevo se produce la autogestación de otro interlocutor, a partir del omnipresente hombre de negro, como siempre: suena el teléfono, el entrevistador dice que la llamada será para él y le pide a Carmen que conteste en su nombre que se ha ido ya. Estamos en el cap. V. Hay una voz de mujer con acento canario o andaluz al otro lado del auricular que pregunta por Alejandro. La narradora entonces se evade a su mundo pasado y rememora a otro Alejandro, el enamorado de Esmeralda en la novela rosa que Carmen y su amiga escribieran en el instituto de bachillerato salmantino de su adolescencia. La mujer del teléfono confunde a la escritora con una «amiga» de Alejandro, y Carmen duda de que esta situación telefónica actual y la otra rememorada de su novela adolescente no «formen parte de la misma intriga ${ }^{25}$. Se sugiere así, por mor del nombre supuesto del entrevistador, el mecanismo literario-ficticio que ha generado dicho interlocutor. Aunque sea en el momento mismo en que éste, el hombre de negro, está gestando, a su vez, otro interlocutor, mera voz que llega sólo a través del hilo telefónico y responde al nombre de Carola. Esta voz será la directora de la novela durante el cap. V.

Guiada por el auricular de Carola, Carmen recuerda su vida pasada, trae a colación las canciones de la postguerra y hace una disquisición ensayística sobre la diferencia entre los boleros, abogados de la esperanza, y las tonadillas, espejo de la realidad cruda y cruel de las mujeres marginadas, llegando a afirmar sobre la conocida canción Tatuaje, que "se convertía, en la voz quebrada de Conchita Piquer, en lo mas real y tangible, en eterno talismán de amor» ${ }^{26}$. El ámbito dominante del sueño, sin embargo, aparece con claridad de nuevo, a propósito de la incertidumbre ambigua que llena la personalidad de este Alejandro, escritor de cartas de amor dirigidas $a$ C. (¿a Carmen?); ¿Interlocutor ficticio o enamorado real de la escritora? $Y$ es que: «Hay un punto en que la literatura de misterio franquea el umbral de lo maravilloso, y a partir de ahí, todo es posible y verosímil» ${ }^{27}$. Lo misterioso-fantástico se corrobora cuando Carola, finalmente, va a leer por teléfono algunas cartas de amor a Carmen..., sin embargo, empieza a discutir con otro hombre, y la narradora siente el presagio de que no leerá epístola alguna: «como ese raro presagio que se introduce en los sueños inopinadamente, insinuando la sospe-

24 El cuarto de atrás, p. 137.

25 Ibid., p. 147

26 Ibid., p. 154.

27 Ibid., p. 166. 
cha de su inconsistencia, avisando de la proximidad del despertar. "Termino enseguida». Es horrible, no le va a dar tiempo a leerme las cartas." $Y$ así es, en efecto, como en un sueño, acaba el cap. $V$ sin que Carola lea ninguna misiva a a la escritora.

Con el cap. VI vuelve a ser catalizador del relato el hombre de negro, y los materiales autobiográficos se concretan en el recuerdo de «la isla de Bergai», creación ficticia de Carmen y de su amiga de Instituto en Salamanca, cuyo nombre estaba formado por las iniciales de ambas adolescentes; refugio seguro para las dos, dado su carácter de mera invención; valido incluso hoy día, a pesar de que su amiga ya esté muerta. A continuación, la narradora explica la situación espacial del «cuarto de atrás» en su casa salmantina, y cómo fue poco a poco cambiando, a consecuencia de la guerra, y convirtiéndose en despensa. Con ello, lo puramente biográfico toca ya a su fin, y la novela se prepara asimismo para acabar, no sin antes reasumir lo vital y lo fantástico en un comentario sobre «la isla de Bergai» que bien podría servir como síntesis ficticio-biografica de esta compleja narración: «Mi amiga me lo había enseñado, me había descubierto el placer de la evasión solitaria, esa capacidad de invención que nos hace sentimos a salvo de la muerte» ${ }^{28}$.

Después ya sólo queda volver a la realidad, despertar del sueño creador y rememorador; y para ello aparece un interlocutor nuevo, bien que real: su hija, que saca a Carmen de los ámbitos de Morfeo en el cap. VII. La novela está ya conclusa como narración y como metanarración. El hombre de negro ha desaparecido. Sin embargo, quedan testimonios de que quizá, quién sabe, pudiera haber estado verdaderamente allí, a pesar de la gran cantidad de datos que avalan su carácter ficticio. Y es que la incertidumbre, la duda y la ambigüedad son elementos fundamentales para la narración fantástica, que aquí se une indisolublemente al recuerdo biográfico verdadero; al igual que se armonizan las fechas más rigurosas y los nombres históricos y reales con el misterio, el sueño y la ficción más pura; del mismo modo que se dan la mano el desorden temporal y el orden cronológico, el pasado y el presente, la adolescencia y la madurez... Y la clave de todo el sistema, radica en el interlocutor, en perfecta coherencia con lo que Carmen Martín Gaite dice y hace, porque la coherencia entre teoría y práctica es, como espero haber demostrado, total, y se constituye en uno de los valores más sólidos de esta escritora. No acabo de entender por qué se le reprocha, en ocasiones, la reiteración de temas y motivos: ¿qué otra manera hay de profundizar, de ahondar en algo que es, a un tiempo, literatura y vida, preocupación psicológica y necesidad

28 El cuarto de atrás, p. 195. 
creadora? Aparte de que el tema en sí mismo considerado nunca ha sido la clave del arte, a lo que se me alcanza.

Para Carmen Martín Gaite los conflictos humanos, los problemas españoles, y las preocupaciones personales forman un todo inseparable Con las investigaciones sobre la esencia de la narración literaria. No hay fisuras ni diferencias, sino armonización y concordancia entre todos esos elementos. Su mundo es un todo ficticio y real, literario y vital al mismo tiempo. El interlocutor dirige su relato y resucita su vida simultáneamente, porque su importancia es completa y total, novelesca y autobiográfica. Necesitamos buenos receptores para vivir y para escribir, para sentir y para crear, para recuperar el pasado inventándolo y para inventar el relato con los materiales auténticos de nuestra propia biografía. La coherencia plena me parece, en todo caso, una cualidad muy destacable y el fruto difícil de un magno esfuerzo reflexivo y creativo, de una vida, en suma -es la coherencia dentro de la coherenciadedicada a la literatura: «...la esencia y las motivaciones del decir, el contar y el inventar, me vienen preocupando desde hace tanto tiempo e interesando con tanta asiduidad que (...) puedo afirmar que nunca en mi vida me he detenido con verdadera complacencia a pensar en otra cosa» ${ }^{29}$.

\section{EL INTERLOCUTOR DE C. MARTIN GAITE Y EL INTERLOCUTOR BARROCO Y Cervantino}

Junto a la consistencia del mundo teórico y creador, hemos insistido en la importancia clave del interlocutor, y lo hemos hecho porque así es, en efecto, y así lo dice ademas la autora. Ella insiste una y otra vez en ello, y no sólo en los textos que hemos citado, sino en otros, como El cuento de nunca acabar, donde se reitera que: «la narración dentro de la narración (es) recurso del que casi ninguna novela es capaz de prescindir y con el que se cuenta habitualmente» ${ }^{30}$. El interlocutor dirige, condiciona, guía, cataliza, ramifica las novelas, aunque no hable... Así lo dice y así lo hace. En El cuarto de atrás hemos visto diferentes interlocutores; uno fundamental que habla y conduce expresamente la novela, que aparece y desaparece intermitentemente durante el núcleo del relato (caps. II, IV y VI) para gestar la creación de otros nuevos (el

29 El cuento de nunca acabar (1983), cito por la ed. de Barcelona, Anagrama, 1988, p. 69.

30 P. 20. Cf., además, pp. 113-120 y 243-246. 
espejo y el aparador en el cap. III y la voz telefónica de Carola en el cap. V); y otros dos diferentes: el autor de la carta desmesurada, cap. I, y la hija de la escritora en el cap. VII. Unos hablan y otros no, unos tienen corporeidad física y otros son meras voces. Todos son importantes, aunque el fundamental es, como hemos reiterado, el hombre de negro.

En la novela del Siglo de Oro español el interlocutor es asimismo de capital importancia; más aún, es el recurso central de la poética implícita, no escrita, de la narrativa áurea. A partir ya de los nuevos géneros que se crean a mediados del XVI, la novela se fragua desde la primera persona de un personaje que se dirige siempre a un receptor, determinado o no: la primera novela bizantina, Los trabajos de Clareo y Florisea (1552) de Alonso Núñez de Reinoso, es el relato autobiográfico de uno de los personajes llamado Isea; $E l$ abencerraje (1551-1565), primera novela morisca, inserta la narración autobiográfica en primera persona del moro, dirigida a Rodrigo de Narváez; El Lazarillo (1554), novela picaresca fundacional, es la autobiografía que Lázaro escribe para Vuestra Merced; y, en fin, La Diana (1559) de Montemayor, narración inaugural de la novela pastoril, se forma con los relatos de Selvagia, Felismena y Belisa, que se los cuentan, en primera persona, a sus acompañantes. Después, ya en el Barroco, casi todas las colecciones de novelas cortesanas son enmarcadas, son narraciones dentro de la narración. Así se conciben la mayor parte de las obras novelescas de María de Zayas, Castillo Solórzano, Salas barbadillo, Céspedes, Tirso de Molina, etc. Lope de vega escribe sus cuatro novelas cortas a Marcia Leonarda, e interrumpe el discurrir del relato con apelaciones a la destinataria. Cervantes utiliza el recurso en la mayor parte de sus creaciones... En fin, para qué seguir. El procedimiento es casi general.

Por ello, me resulta un si es no es chocante que Carmen Martín Gaite no aluda a ningún escritor español de esa época a propósito del interlocutor. Sí cita, en cambio, Las mil y una noches; o se refiere al padre Sarmiento, cuando dice: «La elocuencia no está en el que habla, sino en el que escucha...: si no precede esa función en el que oye, no hay retórica que alcance» ${ }^{31}$; y también menciona a Unamuno, cuando afirma: «No sé hablar si no veo unos ojos que me miran y no siento detrás de ellos un espíritu que me atiende» ${ }^{32}$. Pero no a Cervantes, ni al autor del Lazarillo, que utilizaron al interlocutor con sabiduría y maestría novelesca sin par. Aunque todo encuentra sentido, bien es verdad, al constatar que ella no acepta que el procedimiento sea sólo herencia

31 «La búsqueda del interlocutor», pp. 24-25.

32 El cuento de nunca acabar, p. 113. 
literaria: «es equivocado limitarse a ver la mera pervivencia de una técnica heredada. Yo me resisto a ello. Bien o mal empleado, este recurso, cada vez que aparece es reflejo de una intrínseca necesidad del relato, $y$, aunque no niego que puede pesar la herencia literaria, me inclino a suponer que, si no estuviera inventado, se inventaría espontáneamente» ${ }^{33}$. Y tiene razón, sin duda.

No obstante, es muy probable que una reflexión profunda sobre algunos textos áureos españoles hubiera ayudado considerablemente en el ahondamiento de las posibilidades literarias del interlocutor. En todo caso, sea o no sea así, me interesa constatar la modernidad, por lo demás incuestionable, de Cervantes y del Lazarillo de Tormes; quiero subrayar la pervivencia de estos viejos textos, basándome en la comparación de sus «interlocutores» con los que acabamos de ver en la obra de Carmen Martín Gaite, dado que dicha novelística se centra especialmente en tal cuestión, y, en menor medida, en otros narradores contemporáneos, como Cela. Creo que el breve cotejo merece la pena, aunque sólo sea para defender la actualidad de los clásicos hispanos, tan injustamente olvidados, en ocasiones.

$\mathrm{Ni}$ el desconocido hombre de la playa, autor de la enorme carta, ni, desde luego, el espejo o el aparador, hablan en El cuarto de atrás, aunque ello no impide que guíen el relato, como ya advertía la autora en Retahilas. Pues bien, tampoco abre la boca el destinatario de la epístola autobiográfica que es El Lazarillo de Tormes, "Vuestra Merced», y a pesar de ello dirige la novela. $\mathrm{Y}$ no sólo por ser el pretexto histórico-literario para que un desgraciado se atreva a contar su vida, sino también, y lo que es más importante, por razones internas del texto: no sabemos quién es «Vuestra Merced», pero sí podemos suponer que se trata de un personaje de elevada categoría social, posiblemente una alta dignidad eclesiástica toledana (por el contexto); ello le permite pedir al pícaro que relate el episodio final de su autobiografía, el «caso», esto es, la anómala situación de Lázaro según la cual un simple pregonero, casado con la barragana de un clérigo, asegura a pesar de ello que tiene honra, y lo defiende ante todos, no obstante el deshonor evidente que tal situacion implica. El interlocutor no habla, aunque sí lo hace el pícaro, y por él sabemos que le había solicitado la narración, aunque Lázaro decidiera no relatar sólo el "caso», sino toda su vida anterior, para explicarlo adecuadamente: "Y pues Vuestra Merced escribe se le escriba y relate el caso muy por extenso - dice en el prólogo-, paresciome tomalle del principio y no del medio porque se tenga entera noticia de mi persona». "Vuestra Merced» no habla pero sí diri-

33 «La búsqueda del interlocutor», pp. 27. 
ge por completo la novela, hasta el punto de implicar la perspectiva de escritura (de abajo a arriba) y, simultáneamente, la perspectiva de lectura (de arriba a abajo) de la obra, dado que los lectores de la época se situarían, obviamente, en su posición ante la honra, y no en la de Lázaro. Más aún, este interlocutor implica la polisemia del Lazarillo, dada la coherencia de la autobiografía, puesto que si Lázaro dice encontrarse «en la cumbre de toda buena fortuna», y esto es lógico desde su punto de vista, no lo es desde el de Vuestra Merced, y en esa disparidad, buscada así por el autor del texto, reside la clave del obligado multiperspectivismo de la lectura de esta obra genial. Porque si Lázaro es coherente con su vida y el lector no acepta su ascenso, es porque su punto de vista es muy diferente (el grupo social del pícaro no sabía leer en la España quinientista). El Lazarillo es una novela que sólo tiene sentido en el momento de la lectura, y este sentido es diferente para cada lector, que se sitúa siempre en una posición más próxima a la del Vuestra Merced que a la del pícaro.

El interlocutor de la primera novela picaresca española, en suma, sin intervenir directamente en ella, es quien la conduce y dota de polisemia; y ello de manera espléndida, por cierto, sobre todo si pensamos que se escribió hace cuatrocientos cuarenta años. Los de la novela de Carmen Martín Gaite son de menor importancia, son secundarios, pues aunque también la dirigen, no aportan la riqueza polisémica que aportaba el del anónimo quinientista. Bien es verdad que no es éste el propósito de la autora; pero, en todo caso, puestos a reflexionar sobre la función del interlocutor mudo, quizá podría haber aportado algo la consideración de este clásico español.

Sí es el caso, sin embargo, del receptor de la excelente novela que es $L a$ familia de Pascual Duarte, de Cela: me refiero al abogado emeritense don Joaquín Barrera López, destinatario de las cuartillas autobiográficas de Pascual, tan carente de voz como el «Vuestra Merced» del Lazarillo, y tan importante para dirigir la óptica del narrador y el punto de vista del lector como aquél, asimismo en un trazado de escritura de abajo a arriba y en una respuesta lectora de arriba a abajo. Tan encumbrado está en la escala social el letrado de Mérida como el innominado interlocutor del anónimo quinientista, y tan arrastrado en sus primeros escalones permanece el reo de Torremejía como el pícaro del Tormes. Es obvio que el armazón constructivo de la primera novela de Cela procede del Lazarillo, como epístola autobiográfica que es, y que dicho molde constituye una de las claves de la calidad narrativa de esta novela, que, dicho sea de paso, nada tiene que ver morfológicamente con el Buscón de Quevedo, por más que la autobiografía del extremeño condenado a muerte comience como la del pícaro segoviano seiscentista, diciendo el héroe-narrador 
de aquélla: «Yo, señor, no soy malo»; al igual, casi, que el protagonista y novelista quevedesco: «Yo, señor, soy de Segovia».

El interlocutor fundamental de El cuarto de atrás, con todo, sí habla e interviene directamente en la narración hasta el punto de llegar a usurpar el eje de la misma: «Han vuelto a pasar a sus manos las riendas del argumento principal - dice la narradora-, ahora yo actúo como una mera comparsa» ${ }^{34}$. Y de este tipo, obvio es decirlo, hay muchos casos en la novelística barroca española; aunque limitaré mis referencias al mejor ejemplo de todos, al que aparece en la excelente bilogía cervantina que constituyen El casamiento engañoso y El coloquio de Los perros.

El hombre de negro conduce el relato de muy distintas maneras y hace preguntas variadas, aunque insiste en un tema: el de la teoría y la crítica literarias. Ya hemos visto algunas de sus intervenciones; recordemos otras de este tenor:

- «La ambigüedad es la clave de la literatura de misterio - dice el hombre de negro-, no saber si aquello que se ha visto es verdad o mentira, no saberlo nunca» (p. 53).

- «Si ya fuera un libro no nos estaríamos divirtiendo tanto esta noche, las cosas sólo valen mientras se están haciendo, ¿no cree?» (dice a propósito de Usos amorosos de la postguerra española) (p. 129)

- «Claro, lo importante es saber contar la historia de lo que se ha perdido, de Bergai, de las cartas..., así vuelven a vivir» (pp. 195-196).

- «Usted sabe que el otro jugador es un pretexto.

-Bueno, pero pretexto o no. tiene que existir (...).

-Usted no necesita que exista, usted si no existe, lo inventa, y si existe, lo transforma» (p. 196).

- «Perfecto - dice-. Pues atrévase a contarla, partiendo justamente de esa sensación. que no se sepa si lo que cuenta lo ha vivido o no, que no lo sepa usted misma. Resultaría una gran novela» (p. 197).

— «Entiende usted mucho de literatura, efectivamente (dice la narradora).

—Y usted también — dice—, hoy lo ha dejado claro...» (p. 198).

Curiosamente, lo mismo hace Cipión con respecto a Berganza en El coloquio de los perros, es decir, no cuenta nada tampoco de su vida, se limita a escuchar la narración que hace el otro perro, pero sí la dirige y la guía, en este caso de manera expresa, aconsejando constantemente a su amigo que no de-

${ }^{34}$ El cuarto de atrós, p. 200. 
tenga el hilo de su cuento, que no haga digresiones accesorias, que siga adelante con el tema principal del mismo: «murmura, pica y pasa»; «di adelante»; «basta, Berganza, vuelve a tu senda y camina»; «sé breve, y cuenta lo que quisieres y como quisieres»; «mas quédese aquí esto, que no quiero que parezcamos predicadores. Pasa adelante»; «Basta, adelante, Berganza, que ya estás entendido"; "por tu vida que calles y sigas tu historia... sin que la hagas que parezca pulpo, según le vas añadiendo colas»; «adelante, y no hagas soga, por no decir cola de tu historia»; «sigue tu historia y no te desvíes del camino carretero con impertinentes digresiones»; «no te diviertas; pasa adelante»; «no más, Berganza; no volvamos a lo pasado, sigue»; etcétera.

El Cipión cervantino, como el entrevistador de Carmen Martín Gaite, es el verdadero conductor del relato, también autobiográfico, de Berganza. Sus intervenciones son asimismo teóricas y crítico-literarias, pues responden a una concepción de la novela muy concreta, en este caso muy diferente a la contemporánea de Mateo Alemán (Guzmán de Alfarache, 1599-1604) o López de Ubeda (La Pícara Justina, 1605): la de Cervantes. Al igual que las del hombre de negro se parecen como una gota de agua a otra gota a las de Carmen Martín Gaite. Las similitudes entre ambos interlocutores son muchas.

El entramado cervantino, como se sabe, es, en cambio, muy distinto, porque este juego emisor-receptor se halla inserto dentro de otro paralelo, ya que el peculiar autor del Coloquio es el alférez Campuzano, protagonista de $\mathrm{El} \mathrm{Ca}$ samiento engañoso, relato en el que cuenta su fracasada experiencia matrimonial a su amigo el licenciado Peralta, otro interlocutor de excepcional importancia. Tan es así, que la narración en primera persona del alférez indica que fue objeto de un engaño por parte de dona Estefanía Caicedo, hasta que interviene Peralta, y entonces nos enteramos, los lectores y el licenciado, de que el engaño había sido mutuo entre los dos cónyuges. Y es que Cervantes piensa, como Carmen Martín Gaite, que la primera persona por sí sola no vale para narrar adecuadamente, y hace su portavoz al licenciado. Peralta, espléndido interlocutor, no se cree demasiado el cuento del alférez, pero cuando éste le dice que ha escrito la conversación de dos perros, ya no le cree nada, aunque se apresta a leer la novela a causa del «buen ingenio» de Campuzano. Éste, por cierto, no sabe si vio, o si oyó, o si casi vio hablar a los dos perros de Mahudes, aunque, finalizada la lectura el licenciado Peralta zanja la cuestión, también crítico-literariamente (como Cipión o como el hombre de negro), y dejando al margen la cuestión de la veracidad, dice: «Yo alcanzo el artificio del Coloquio, y la invención, y basta.»

La utilización de Cervantes es, pues, muy diferente a la de nuestra escritora, ya que reduplica el juego de los interlocutores y hace a uno lector del otro, dotando al conjunto de una grandeza novelesca sin par en su época e 
inaugurando la novela moderna magníficamente ${ }^{35}$. Los parecidos también son obvios, pues los materiales autobiográficos (aunque en Cervantes sean de cariz picaresco), la incertidumbre, la ambigüedad, la duplicación de personalidad, la inversión temporal y la fantasía son comunes. No se olvide que se trata de dos perros que han adquirido, ápice de la fantasía, el portentoso don de la palabra y del razonamiento, además de una ética de comportamiento; ni que no saben si son dos niños, hijos de una bruja llamada La Montiela, transformados por otra bruja, La Camacha, en perros; ni, por último, si son hijos de un ganapán, o del mismo demonio. La comparación, por ello, me parece pertinente.

No pretendo entrar, desde luego, en cuestiones de calidad literaria, sino demostrar la actualidad y modernidad de algunos de nuestros mejores clásicos; y eso creo que ha quedado suficientemente probado, bien que de manera sumaria; porque el uso literario que hacen del interlocutor no desmerece en absoluto del que se practica ahora mismo. Sí pienso, en consecuencia, que una lectura meditada de sus potencialidades narrativas habría dotado aún de mayor complejidad y riqueza estéticas la más que notable profundidad del pensamiento novelesco de Carmen Martín Gaite.

35 Me he ocupado de este asunto en «Género y estructura de El Coloquio de los perros, o "cómo se hace una novela"», en Lenguaje, ideología y organización textual en Las Novelas Ejemplares. de Cervantes, Madrid, Univ. Complutense, 1983, pp. 119-144. 